\title{
Şiî Usûl Düşüncesinde İctihad Bağlamında Muâz Hadisinin Değeri
}

\author{
Ömer Korkmaz \\ Dr. Öğr. Üyesi, Çukurova Üniversitesi (ROR ID: 05wxkj555) \\ İlahiyat Fakültesi, İslam Hukuku Anabilim Dalı \\ Assistant Professor Dr., Çukurova University, Faculty of Theology, Department of Islamic Law \\ Adana/Turkey \\ okorkmaz@cu.edu.tr \\ ORCID: 0000-0002-8070-5398
}

\section{The Value of the Mu'ādh Hadīth in the Context of Ijtihād in the Tought of Shīî̀s Usūl Abstract}

When $\mathrm{Mu}^{\text {'ādh }}$ was sent to Yemen as governor, the hadith that describes the answer of Mu'ādh which "I will rule with Qur'ān, sunnah, and my opinion." to the Prophet's question that "What will you rule with? is known as the Mu'ādh hadith. This hadith was accepted by the majority of Sunni scholars and was used to prove that it was one of the shar'i proofs of the qiyās. On the other hand, since the Shīi ì scholars did not accept the qiyās, they rejected this hadīth and claimed that it was false. However, the Shi'i i scholars argued that even if it is accepted to be true, this hadith shows that it is not permissible to apply to the qiyās in the presence of the Nass (Qur'ān and Sunnah), and also stated that this can not be evidence of the qiyās. In addition, they do not accept the famous form of the Mu'âdh hadith, as well as they put forward another variant of the hadith which states that "In the resolution of issues that have no verdict in Qur'ān 'and Sunnah, should be asked to the Prophet". The highlighting of the narrative, which states that "Mu'ādh asked the Prophet and waited for an answer on a subject that he could not find any Nass", had a very important result in favor of Shīa. This is because the Mu'âdh hadith, which is famous in Sunni sources, both shows that the qiyās is a shar'i evidence and contradicts the idea of imāms that must be found in every period. However, the narrative in the form of "No! Write/ask me, I write to you/I will answer", that supports the understanding of imāmah and wants to be consulted to the opinion of the imām, not the qiyās. In this study, it will be examined whether the effect of the understanding of innocent imāms on the Mu'ādh hadith as false by the Shĩ a and how they interpret this hadith which is presented as a strong proof of the qiyās.

The Mu'ādh Hadith, presented by the Ahl al-Sunnah as a strong proof of qiyās, contains information contrary to the idea of imamate and the existence of the imam. Because if there is ijtihād, an imam will not be needed. As mentioned in the research, the imam to Shi'a is both the source and interpreter of the Nass. Therefore, the presence of the imam hinders someone else's ijtihād. For this reason, the Shīa usūlists argue that the Mu'ādh Hadīth is not sahỉh, and even if it was

Intihal Taraması/Plagiarism Detection: Bu makale intihal taramasından geçirildi/This paper was checked for plagiarism Geliş/Received: 01 Ocak/January 2020 | Kabul/Accepted: 08 Mayı/May 2020 | Yayın/Published: 20 Eylül/September 2020 Atıf/Cite as: Ömer Korkmaz, "Şî̂ Usûl Düşüncesinde İctihad Bağlamında Muâz Hadisinin Değeri = The Value of the Mu'ādh Hadith in the Context of Ijtihād in the Tought of Shī'î's Usūl”, Eskiyeni 42 (Eylül/September 2020), 909-925 https://doi.org/10.37697/eskiyeni.668889

Copyright @ Anadolu İlahiyat Akademisi/Anatolian Theological Academy, 06050, Ankara, Turkey | www.anilakademi.com CC BY-NC 4.0 | This paper is licensed under a Creative Commons Attribution-NonCommercial License 
deemed sahïh, it would not point to qiyās as claimed by the Ahl al-Sunnah. In addition, the Shīa 'ulamā' claim that there is a different variant of the Mu'âdh Hadith and that this version of the hadith is more suitable to be proof. According to this version, the Prophet asks Mu'ādh "How will you judge if you cannot find the verdict of the case offered to you in the Book of Allah or the Sunnah of the Messenger of Allah?" and when Mu'ādh gives the answer "I'll act upon my ra'y and ijtihād (ajtahidu bi-ra'yī)", the Prophet says "No! Write/ask me and I will write/answer you.". Therefore, according to this riwayah, Mu'ādh would not turn to ijtihād for the subjects for which he couldn't find the answers in the Book or Sunnah and, on the contrary, he would have to wait for the answer of the Prophet.

Arguing that qiyās is batil, Shī'a usūlists highlighted this variant of the Mu'ādh Hadīth. As can be seen, emphasizing this riwayah, which specifies "asking the Prophet and waiting for the answer", reveals a very important outcome in favor of Shīa. Because in its mashhur (well known) form, the Mu'ādh Hadith both shows that ra'y/qiyās is a Shar'i proof and it contradicts the idea of imamate, which is considered to be mandatory at all times, and therefore Shi'a's idea of sunnah. In the riwayah put forward by Shi'a, the answer of the Prophet in the form of "No! Write/ask me and I will write/answer you." emphasizes the idea of imamate and directs people to consult the imam instead of the ijtihādī opinion. Accordingly, Shīa 'ulamā' should not resort to ijtihād but ask the ma'sum imam for the solution of a matter that is not included in the Qur'an and Sunnah. As a result, it is understood that the understanding of the ma'sum imam, which plays an important role in the interpretation of the 'Âyāt and the hadīth that are in the Sunni sources, is also effective in the interpretation of the Mu'âdh Hadith.

\section{Keywords}

Islamic Law, Shī‘a, Ja'farī, Mu'ādh Hadīth, Ijtihād, Innocent Imām

\section{Öz}

\section{Şî̂ Usûl Düşüncesinde İctihad Bağlamında Muâz Hadisinin Değeri}

Muâz hadisi olarak bilinen ve Yemen'e vali olarak gönderildiğinde Hz. Peygamber'in "Ne ile hükmedeceksin?" sorusuna Muâz b. Cebel'in sırasıyla kitapla, sünnetle ve re'yimle şeklinde cevap verdiğinin rivayet edildiği hadis, Sünnî usûl âlimlerinin büyük çoğunluğu tarafindan kabul görmüş ve kıyasın şerî̀ delillerinden biri olduğunu ispat için kullanılmıştır. Buna mukabil Şiî âlimler kıyası kabul etmedikleri için bu hadisi reddetmişler ve batıl olduğunu iddia etmişlerdir. Bununla birlikte Şiî âlimler, sahih olduğu kabul edilse bile bu hadisin nas varken kıyasa başvurulmasının caiz olmadığını gösterdiğini ve kıyasın delillerinden olamayacağını belirtmişlerdir. Ayrıca onlar Muâz hadisini bilinen meşhur şekliyle kabul etmedikleri gibi hadisin “Kur'ân ve Sünnet’te hükmü bulunmayan meselelerin çözümünde Hz. Peygamber'e sorulması gerektiğini” belirten başka bir varyantını öne çıkarmışlardır. "Muâz’ın herhangi bir nas bulamadığı bir konuda Hz. Peygamber'e sorması ve cevabını beklemesi”ni ifade eden rivayetin öne çıkarılması Şia lehine çok önemli bir sonuç doğurmaktadır. Zira Sünnî kaynaklarda meşhur olduğu şekliyle Muâz hadisi hem re'yin/kıyasın şer'î bir delil olduğunu göstermekte hem de her dönemde bulunması zorunlu olan imam fikrine aykırılık arz etmektedir. Buna karşın "Hayır! Bana yaz/sor, ben de sana yazarım/cevap veririm” şeklindeki rivayet ise imamet anlayışını desteklemekte ve kıyasa değil imamın görüşüne müracaat edilmesini istemektedir. Bu araştırmada Şia'nın kıyasın güçlü bir delili olarak sunulan Muâz hadisini batıl olarak nitelemelerinde, masum imam anlayışının etkisinin olup olmadığı incelenerek ilgili hadisi nasıl yorumladıkları ele alınacaktır. 
Ehl-i Sünnet tarafından kıyasın güçlü bir delili olarak sunulan Muâz hadisi imamet fikrine ve imamın varlığına aykırı bilgiler ihtiva etmektedir. Araştırmada geçtiği üzere Şia'da imam hem nassın kaynağı hem de yorumcusudur. Dolayısıyla imamın varlığı başkasının ictihad edebilmesine engel teşkil etmektedir. Bu nedenle Şiî usûlcüler Muâz hadisinin sahih olmadığını, sahih olduğu kabul edildiği takdirde de Ehl-i Sünnet tarafından iddia edildiği gibi kıyasa delalet etmediğini savunurlar. Buna ilaveten Şiî âlimler, Muâz hadisinin farklı bir varyantının olduğunu dile getirerek hadisin bu tarikinin delil olmaya daha elverişli olduğunu iddia ederler. Buna göre Hz. Peygamber Muâz'a “Sana arz edilen davanın hükmünü Allah'ın Kitab'ında ve Resûlullâh'ın Sünnet'inde bulamazsan nasıl hükmedeceksin?" diye sorduğunda onun "Re'y ve ictihadımla amel ederim/hükmederim (ectehidu bi-ra'yî)” demesi üzerine Hz. Peygamber "Hayır! Bana yaz/sor, ben de sana yazarım/cevap veririm" demiştir. Dolayısıyla bu rivayete göre Muâz çözümünü Kitap ve Sünnet'te bulamadığı konularda ictihad edemeyecek aksine Hz. Peygamber'in cevabını beklemek zorunda kalacaktır.

Kıyasın batıl olduğunu belirten Şî̂ usûlcüler Muâz hadisinin söz konusu varyantını öne çıarmışlardır. Görüldüğü üzere “Hz. Peygamber’e sorması ve cevabını beklemesi”ni ifade eden bu rivayetin öne çıkarılması ve vurgulanması Şia lehine çok önemli bir sonuç doğurmaktadır. Zira Sünnî kaynaklardaki meşhur varyantıyla Muâz hadisi hem re'yin/kıyasın şerî̀ bir delil olduğunu göstermekte hem de imamet fikrine aykırılık ifade etmektedir. Şia’nın öne çıkardığı rivayette Hz. Peygamber'in "Hayır! Bana yaz/sor, ben de sana yazarım/cevap veririm" şeklindeki cevabı imamet fikrine vurgu yapmakta ve kıyasa yani hür ictihadî görüşe değil imamın görüşüne müracaat edilmesini istemektedir. Buna göre hükmü Kur’ân ve Sünnet'te yer almayan bir meselenin çözümünde Şiî âlimlerin ictihada başvurmayıp masum imama sormaları gerekmektedir. Sonuç olarak âyetlerin ve Sünnî hadis kaynaklarında yer alan hadislerin yorumlanmasında önemli bir fonksiyon icra eden masum imam anlayışının Muâz hadisinin yorumlanmasında da etkili olduğu anlaşılmaktadır.

\section{Anahtar Kelimeler}

İslam Hukuku, Şia, Caferî, Muâz Hadisi, İctihad, Masum İmam

\section{Giriş}

Sünnî ilim halkaları 2./8. yüzyılın sonlarına kadar Şia mezhebinin anlayışını benimseyenlere ${ }^{1}$ açı olmuştur. Bu durumun sonucu olarak her iki grup arasında bilgi geçişkenliğinin olması da normal karşılanmıştır. 190 (805) yılından sonra ise Sünnî toplumdan dişlanan Şia'nın mezhepsel kabullerinin netleşmeye başlaması ve kendi ilim halkalarını sürdürebilecek ilmî birikime kavuşması, müstakil Şiî ilim halkalarının oluşmasına ve iki ekol arasında yorum farklılıklarının ortaya çıkmasina neden olmuştur. ${ }^{2}$

1 Şia mezhebi kurumsal olarak o dönemde mevcut olmamakla birlikte mezhebin anlayışını benimseyenler erken dönemlerden itibaren vardı. İlk olarak Hz. Ali ile Muâviye arasındaki mücadelede Hz. Ali'nin yanında yer alan Kûfe yerleşimcileri, daha sonra Emevi iktidarına muhalefet edenler, gaybet ve rec'at anlayışına sahip olanlar burada zikredilebilir. Detaylı bilgi için bk. Cemil Hakyemez, Şîa'da Gaybet İnancı ve Gâib On İkinci İmam (İstanbul: İsam Yayınları, 2009), 27-41.

2 Konuyla ilgili örnek hadisler ve değerlendirmeler için bk. Muhammed Enes Topgül, "Sünnî-Şî̂ İkilemine Farklı Bir Bakış: Yeniden İnşa Edilen Hadis Bağlamları”, İslâm Araştırmaları Dergisi 41 (2019), 47. 
Şia'nın Ehl-i Sünnet’ten ve diğer muhalif gruplardan ayrı olmasını sağlayan birincil etken, üzerine mezheplerini bina ettikleri müstakil hadis ve tarih malzemesine/bilgisine sahip olmalarıdır. ${ }^{3}$ Dolayısıyla sahip oldukları bu hadis ve tarih malzemesini korumak Şia mezhebi için hayati öneme sahiptir. Bu durum, Şiî âlimlerin anlayışlarına aykırı bilgi ve rivayetlere karşı savunmacı tutum geliştirmelerini ve rivayetleri mezhep anlayışlarına göre yorumlamalarını zorunlu kılmıştır.

Esasen Caferî fikıh usûlü eserleri incelendiğinde büyük oranda Sünnî eserler ile mutabakat halinde olduğu görülmektedir. İki tarafın en büyük ayrılık noktasını kıyas ve sünnet konusu teşkil etmektedir. Öyle ki Şia'daki hadis rivayeti, kendilerini Ehl-i Sünnet'ten ayıran önemli unsurlardan biri olan imamet fikrini güçlü bir şekilde vurgulamasıyla ön plana çıkar. ${ }^{4}$ Muâz hadisinin içeriğine bakıldığında hem re'yin/kıyasin şerî̀ bir delil olduğundan bahsetmesi hem de her dönemde bulunması zorunlu olan imam anlayışına, dolayısıyla Şia'nın sünnet fikrine aykırı olması nedeniyle Şia mezhebi tarafından hadisin batıl kabul edilmesi doğal karşılanmalıdır. Zira nasların sınırlı meselelerin ise sınırsız olması nedeniyle Sünnî ekollerin kaçınılmaz olarak başvurduğu re'y, ictihad ve kıyas yerine onlar bir imamın var olması fikrini koymaktadırlar. ${ }^{5}$ Şia mezhebinin ${ }^{6}$ anlayışına göre imam masumdur ve ilham/vahy alır. Bunun için de kendisi ictihada ihtiyaç duymadığı gibi imam dışındaki kişilerin de ictihad etmesine gerek yoktur.

Şia'nın imamlarının masum olduğu inanışı söz konusu imamların hadislerinin Hz. Peygamber' in hadisleri gibi bağlayıcı olmasını gerektirmiştir. Bunun sonucu olarak da bu anlayış âyetlerin ve Sünnî hadis kaynaklarında yer alan hadislerin yorumlanmasında önemli bir fonksiyon icra etmiştir. ${ }^{7}$ Bu anlamda masum olan imamın kendisi hem kutsal kaynak hem de onun yorumcusu olmuştur. ${ }^{8}$

Günümüzde yapılan araştırmalarda görüldüğü üzere ilk dönem Şî̂ âlimler tarafindan kıyasa mesafeli durulmuş ya da karşı tutum geliştirilmiş olsa da onlar tarihi seyir içerisinde kıyas adıyla olmasa da aklî delil adı altında kıyası kullanmışlardır. Bu nedenle Caferî fakihler arasında birbirlerine karşı kıyası kullandıklarına dair ithamlar olmuştur. İlk dönemde kıyası reddetmek esas olmakla birlikte olgunlaşma döneminde tevil yöntemi ile belirli sınırlar içerisinde kıyas kabul edilmiştir. ${ }^{9}$ Bu çalışmada Caferî fakihlerin kıyası kabul ettikleri ya da etmedikleri ile ilgili bir yargiya ulaşmak amaçlanmamaktadır. Çalışmanın amacı özellikle kıyasa karşı reddiyeci bir duruş benimsenen ilk dönemlerde Şî̂ âlimlerin, Sünnî gelenekte kıyasın önemli delillerinden biri kabul edilen Muâz

3 Bekir Kuzudişli, “Şia'da Rivayet Olgusunu Şekillendiren Temel Unsurlar”, Dinbilimleri Akademik Araştırma Dergisi 18/1 (2018), 60.

4 Kuzudişli, “Şia'da Rivayet Olgusunu Şekillendiren Temel Unsurlar”, 59.

5 Sefa Atik, Sünnîliğin İzinde Caferî Fıkıh Usulünde Akıl (İstanbul: Pınar Yayınları, 2017), 73.

6 Araştırma boyunca Şia mezhebi ile inanç esasları açısından İmamiyye Şiası ile onun fikıh mezhebi olan Caferî mezhebi kastedilmektedir.

7 Kuzudişli, “Şia'da Rivayet Olgusunu Şekillendiren Temel Unsurlar”, 61.

8 Atik, Sünnîliğin İzinde, 23.

9 Caferî fakihlerin kıyasa karşı tutumunun değişim ve gelişimi ile ilgili detaylı bilgi için bk. Atik, Sünnîliğin İinde, 217-234. 
hadisine yaklaşımlarını göstermektir. Ayrıca Şia'nın masum imam anlayışının Muâz hadisinin batıl olarak nitelenmesinde etkisinin olup olmadı̆̆ incelenerek ilgili hadisin nasil yorumlandığı ele alınacaktır.

\section{Muâz Hadisi ve Sünnî Eserlerde Muâz Hadisinin Kaynak Değeri}

Muâz hadisi olarak bilinen rivayet şöyledir:

“Hz. Peygamber, Muâz b. Cebel'i Yemen'e vali ya da kadı olarak gönderirken aralarında şöyle bir konuşma geçmiştir:

Hz. Peygamber: Sana bir dava getirildiğinde ne ile hüküm vereceksin?

Muâz b. Cebel: Allah'in Kitâbı'nda bulunan hükümler ile hükmedeceğim.

Hz. Peygamber: Eğer Allah'ın Kitâbı'nda o hükmü bulamazsan ne yapacaksın (nasil hükmedeceksin)?

Muâz b. Cebel: Resûlullâh'ın sünnetinde bulunan hükümler ile hükmedeceğim.

Hz. Peygamber: Söz konusu davanın hükmünü Resûlullâh'ın Sünnet'inde bulamazsan nasil hükmedeceksin?

Muâz b. Cebel: Re'y ve ictihadımla amel ederim (hükmederim).

Bunun üzerine Hz. Peygamber elini onun göğsüne koyarak şöyle dedi: Resûlullâh'ın resûlünü Resûlünün razı olacağı şeye muvaffak kılan Allah'a hamdolsun".

Muâz hadisi değişik varyantlarıyla birçok hadis ve fikıh kitaplarında bulunmaktadır. Örneğin bu hadis Ebû Dâvûd Tayâlisî (öl. 204/819) tarafından tasnif edilen ve türünün ilk örneği kabul edilen ${ }^{10}$ el-Müsned ${ }^{11}$ isimli eserde mevcuttur. İmam Şâfî̂ (öl. 204/820) de el-Ümm adlı eserinde iki yerde bu hadisle istidlal etmiş, ${ }^{12}$ hadisin sıhhatiyle ilgili herhangi olumsuz bir ifade zikretmemiştir. Hadisle istidlal etmiş olması onun indinde bu hadisin sahih ve makbul olduğuna delalet etmektedir.

Muâz hadisi Buhârînnin (öl. 256/870) Sahîh'inde geçmemekle birlikte Buhârî söz konusu hadisin senedinde bulunan bir raviyle ilgili değerlendirme yapmaktadır. Buhârî Tarih'inde Hâris b. Amr'ın adının sadece bu rivayette geçtiğini belirterek ravinin mechûl olduğunu ima etmekte ve bu senedle gelen Muâz hadisinin sahih olmadığını belirtmektedir. Ayrıca bu isnad zincirinin mürsel olduğunu ifade etmektedir. ${ }^{13}$

Muâz hadisi Müslim'in (öl. 261/875) Sahîh'inde zikredilmemektedir. Ancak Tirmizî1 ${ }^{14}$

10 Ebû Dâvûd Süleymân b. Dâvûd b. el-Cârûd Tayâlisî, Müsnedu Ebî Dâvûd Tayâlisî, thk. Muhammed b. Abdülmuhsin et-Türkî (Cize: Dâru Hicr li't-Tibâa ve'n-Neşr, 1419/1999), 1/454.

11 M. Yaşar Kandemir, "el-Müsned", TDV İslâm Ansiklopedisi (istanbul: TDV Yayınları, 2006), 32/103; Halit Özkan, "Tayâlisî”, TDV İslâm Ansiklopedisi (İstanbul: TDV Yayınları, 2011), 40/189.

12 Ebû Abdullah Muhammed b. İdris b. Abbas Şâfiî, Kitâbü'l-Üm (Beyrut: Dâru'l-marife, 1410/1990), 6/216; Şâfiî, Kitâbül'-Üm, 7/315.

13 Ebû Abdullah Muhammed b. İsmâîl b. İbrâhîm el-Cu'fî Buhârî, et-Târîhu'-kebîr (Haydarâbâd: Dâru'lmaârifi'l-Osmâniyye, 1361-1364), 2/277.

14 Muhammed b. Îsâ Tirmizî, Sunenu't-Tirmizî, thk. Ahmed Muhammed Şâkir (Misır: Matbaatu Mustafa elBâbî, 1975), "Ahkâm" 3. 
(öl. 279/892), Ebû Dâvûd ${ }^{15}$ (öl. 275/889) ve Dârimî̉nin ${ }^{16}$ (öl. 255/869) Sünenleri, Ahmed b. Hanbel'in (öl. 241/855) Müsned'i, ${ }^{17}$ Tahâvînnin (öl. 321/933) Şerhu Müşkili'l-âsâr' ${ }^{1}{ }^{18}$ Taberânînnin (öl. 360/971) el-Mu'cemu'l-kebî̀r' $1^{19}$ ve Beyhakînnin (öl. 458/1066) es-Sünenü'l-kubrầ's ${ }^{20}$ ile es-Sünenü's-suğrầ ${ }^{2}{ }^{21}$ gibi hadis eserlerinde söz konusu hadise yer verilmektedir. Ayrıca aşağıda yer verileceği üzere erken ve geç dönem birçok fikıh ve fikıh usûlü kitaplarında da bu hadise yer verilmiştir.

Muâz hadisinin sıhhati konusunda özellikle hadisçiler arasında önemli tartışmalar yapılmaktadır. ${ }^{22}$ Ancak bu değerlendirmelerin odak noktasını hadisin ravileri arasında mechul olan kimseler olușturmaktadır. Öncelikle hadisi Muâz b. Cebel'den rivayet edenler hakkında isim verilmeksizin "Muâz'ın ashabı (arkadaşları)", "Muâz'ın arkadaşlarından bir kısım insanlar" şeklinde "nâs", "ünâs" ve "ricâl" gibi bir topluluğu ifade eden tabirler kullanılmaktadır. Bu insanların ise kim oldukları bilinmemektedir (mechûl). Ayrıca hadisi Muâz'in ashabından rivayet eden Hâris b. Amr es-Sekafînin de ismi sadece bu rivayette geçmekte olup kendisi tanınmamaktadır (mechûlü'l-hâl). ${ }^{23}$

Muâz hadisine hadisçiler tarafindan yöneltilen bir diğer tenkit noktası onun mürsel olduğudur. ${ }^{24}$ ilgili rivayetin bazı varyantlarında hadis Muâz zikredilmeksizin Muâz'in ashabından rivayet edilmektedir. Sahabi olan ravi atlanıldığı için hadis mürsel olmaktadır. Bu da hadisin zayıf olduğu noktasında eleştirilmesine neden olmuştur.

15 Ebû Dâvûd Suleymân b. Eş’as Ezdî Sicistânî, Sunenu Ebî Dâvûd, thk. Muhammed Muhyiddîn (Beyrut: elMektebetu'l-Asriyye, ts.), "Akdiye" 11.

16 Abdullâh b. Abdurrahmân Dârimî, Sunenu'd-Dârimî, thk. Huseyn Selim Esed (Riyâd: Dâru'l-Muğnî, 2000), $1 / 267$.

17 Ahmed b. Muhammed İbn Hanbel, Musnedul-Imâm Ahmed b. Hanbel, thk. Şu'ayb Arnâût - Âdil Murşid (b.y.: Muessesetu'r-Risâle, 2001), 36/333.

18 Ebû Ca'fer Ahmed b. Muhammed b. Selâme el-Ezdî el-Hacrî el-Mısrî Tahâvî, Şerhu müşkilil'-âsâr, thk. Şuayb el-Arnaût (Beyrut: Müessesetü'r-risâle, 1415/1994), 9/212.

19 Ebû'l-Kâsım Suleyman b. Ahmed Taberânî, el-Mu'cemu'l-kebîr, thk. Hamdi b. Abdulmecid Selefî (Kâhire: Mektebetu Ibn Teymiyye, 1994), 20/170.

20 Ahmed b. Huseyn b. Ali Beyhakî, es-Sunenu'-kubrâ, thk. Muhammed Abdulkâdir Atâ' (Beyrut: Dâru'lKutubi'l-ilmiyye, 2003), 10/195.

${ }^{21}$ Ahmed b.el-Huseyn b. Ali Beyhakî, es-Sunenu's-suğrâ, thk. Abdulmu'tî Emin Kal'acî. (Pakistan:Câmi atu'dDirâsâti'l-ìslâmiyye, 1989), 4/130.

22 Hadisin shhhatiyle ilgili detaylı değerlendirmeler için bk. Şaban Çiftçi, "Hadis Eğitiminde Usul-Pratik Bütünlüğü “Muâz Hadisi” Örneğı", Abant İzzet Baysal Üniversitesi Eğitim Fakültesi Dergisi 11/2 (2015), 55-64; Sema Gül, "Muâzb. Cebel'in Yemen'e Gönderilmesiyle İlişkilendirilen Rivâyetlerin Şekil Yönünden Tahlili”, Iğdir Üniversitesi İlahiyat Fakültesi Dergisi 6 (2015), 183-208; Mehmet Macit Sevgili, "Bir Usûlcü Olarak Cüveynînnin Hadisçiliği ve Hadisçiliğine Dâir Tartışmalar -"Mu'âz Hadisi” Özelinde-", Sakarya Üniversitesi Illahiyat Fakültesi Dergisi 20/37 (2018), 226-240; Yusuf Akgül, "Fikıh Usulüne Kaynaklı̆̆ Açısından Muâz Hadisinin Tahlili ve Tenkidi”, Bozok Üniversitesi Illahiyat Fakültesi Dergisi 13/14 (2018), 193-222.

23 Ebû Muhammed b. Ali b. Ahmed b. Saîd ez-Zâhirî ỉbn Hazm, el-îhkâm fî usûli'l-ahkâm, thk. Ahmed Muhammed Şâkir (Beyrut: Dâru'l-Âfâki'l-Cedîde, ts.), 7/111-113; Ebû Muhammed b. Ali b. Ahmed b. Sa îd ez-Zâhirî İbn Hazm, el-Muhallâ bil-âsâr (Beyrût: Dâru'l-Fikr, ts.), 1/82.

24 Tirmizî, "Ahkâm” 3; Taberânî, Mu'cem, 20/170; Ebû'l-Hasen Ali b. Ömer Dârekutnî, el-'ilelu'l-vâride fi'ehâdîsin'nebeviyye, thk. Mahfûzu'r-Rahmân Zeynullâh (Riyâd: Dâru Taybe, 1985), 6/88. 
Ancak Said b. Müseyyeb'in dışında kimsenin mürselini kabul etmeyen ve onunla amel etmeyen İmam Şâfiî̀nin -yukarıda geçtiği üzere- bu rivayeti bazı hususlarda delil olarak kullanması onun nezdinde bu rivayetin muttasıl varyantlarının bulunduğu ve kendisinin de bu rivayetleri esas aldığı şeklinde yorumlanabilir. Dolayısıyla rivayetin mürsel olarak aktarılmasının Muâz hadisinin sıhhati açısından bir nakîsa teşkil etmeyeceği söylenebilir.

Muâz hadisi bazı hadisçiler tarafından hadis tekniği açısından zayıf olarak nitelendirilse de usûlcülerin büyük çoğunluğu tarafından kabul görmüş, onlar tarafından kıyasın/ictihadın dayanaklarından biri olarak zikredilmiştir. Örneğin Cessâs (öl. 370/981) Muâz hadisini kitaplarında birçok farklı konuda delil olarak kullanmaktadır. Mesela Ahkâmü'l-Kur'ân'ında, sihhatiyle ilgili olumlu ya da olumsuz bir kanaat bildirmeden "iki durumda Hz. Peygamber hayatta iken dahi ictihad edilebileceğine" delil olarak sunmaktadır. ${ }^{25}$ Tahâvînnin Muhtasar'ı üzerine yazdı̆̆ı şerhte ise Cessâs, kâdînın/hâkimin nas bulunmayan hususta re'y ve ictihad ile hüküm verebileceğini belirterek Muâz hadisini delil getirmekte ve bu hadisin birçok tarikle rivayet edildiğini, ancak uzatmamak için isnadlarını yazmadığını ifade etmektedir. ${ }^{26}$ Cessâs, Muâz hadisinin sıhhatiyle ilgili tartışmalara ise usûl kitabında yer vermekte ve hadisin sahih olduğunu detaylı bir şekilde ele almaktadır.

Cessâs, usûl kitabında Muâz hadisine iki ayrı konuda yer verir. Öncelikle o, ictihad ve re'ye kıyas olmadığı zaman başvurulması gerektiğini delillendirirken Muâz hadisini zikreder ve bu hadisi "Hz. Peygamber'den rivayet edilen insanların/ümmetin/âlimlerin kabul ile telakki ettikleri, yaygın (şâyi') bir nakil” şeklinde tanımlar ve hadisle ilgili kanaatini belirten bir ifade kullanır. ${ }^{27}$ Ona göre bu hadisin Muâz'ın ashabı denilen mechul bir topluluktan rivayet edilmiş olması hadisin sihhatine zarar vermez. Bilakis Muâz'ın ashabına izafe edilmesi hadisin sahih olduğunu teyit eden bir durumdur. Zira Muâz’ın ashabı sîka kimseler olup rivayetleri makbul şahıslardır. Ayrıca bu hadis insanların/ümmetin/âlimlerin kabulüne mazhar olmuş, meşhur ve müstefîz bir rivayettir. Hiç kimse hadisin ravilerini inkâr etmediği gibi hadisi de reddetmemiştir. ${ }^{28}$

Cessâs, Muâz hadisinin mürsel ${ }^{29}$ olduğuna dair yöneltilen eleştiriye de cevap verir. Ona göre bu gibi insanların/ümmetin/âlimlerin kabulüne mazhar olan haberlerin

25 Ebû Bekr Ahmed b. Ali er-Râzî Cessâs, Ahkâmü'l-Kur'ân, thk. Abdüsselam Muhammed Ali Şahin (Beyrut: Dâru'l-kütübi'l-ilmiye, 1415/1994), 2/266.

26 Ebû Bekr Ahmed b. Ali er-Râzî Cessâs, Şerhu Muhtasari't-Tahâvî, thk. İsmetullâh İnâyetüllâh Muhammed vdğ (Beyrut: Dâru Beşâiri'l-İslâmiyye - Dâru's-Sirâc, 2010), 8/23.

${ }^{27}$ Ebû Bekr Ahmed b. Ali er-Râzî Cessâs, el-Fusûl fi'l-usûl (Kuveyt: Vezâretü'l-Evkâfi'l-Kuveytiye, 1994), $2 / 318$.

28 Cessâs, el-Fusûl fi'l-usûl, 4/44-45.

29 Hanefî usûlcüler sahabe sonrası özellikle dördüncü tabaka mürselleri hakkında ihtilaf etmişlerdir. Örneğin Kerhi'ye göre bu tabaka mürsellerinin hepsi delil iken İsa b. Eban'a göre sadece Muhammed b. Hasan gibi ilmiyle meşhur râvilerin mürselleri delil kabul edilir. Ancak Hanefî usûlcüler sahabe dönemine ait mürsellerin delil olacağı hususunda görüş birliği içerisindedir. bk. Fatih Orhan, “İmam Serahsînnin 
önemli bir özelliği zaten mürsel şekilde rivayet edilmeleridir. İctihadın ve kıyasın meşruiyetiyle ilgili birçok habere yer veren Cessâs'a göre metinleri ve tarikleri muhtelif olmakla birlikte bu tür haberlerin ortak noktası "meydana gelen olaylarda ictihada başvurulmasının mubah olduğu"dur. ${ }^{30}$ Hatta Cessâs'a göre ictihadın meşru olduğuna dair ilim ifade eden o kadar çok haber vardır ki meseleyi uzatmak hoş karşılanmadı̆̆ı için bu rivayetlerin isnadları hazfedilmiştir. Zira bu tür haberler ilim ehli katında meşhur haberlerdir (yani isnadlarını zikretmeye ihtiyaç yoktur). ${ }^{31}$ Ayrıca Cessâs, Musa b. Ubeyde'nin Abdullah b. Utbe'den rivayet ettiğini söylediği benzer bir hadis nakletmektedir. Bu hadiste Hz. Peygamber' in Muâz ile Ebû Musa el-Eş‘arî’yi Yemen'e gönderdiği ve Hz. Peygamber ile Muâz ve Ebû Musa el-Eş‘arî arasında yine meşhur Muâz hadisindeki diyaloğun yaşandığı belirtilmektedir. ${ }^{32}$

Muâz hadisini destekleyen bir diğer delil, ortaya çıkan yeni olaylarda sahabenin -şüpheye mahal bırakmayacak şekilde- kıyas ve ictihada başvurmasıdır. Cessâs'a göre sahabenin kıyas ve ictihad yaptı̆̆ına dair rivayet edilen haberler kesin bilgi ifade eden mütevatir haberlerdir. Sahabiler "re'yimle ictihad ediyorum", "bu hususta görüşüm şudur" gibi ifadelerle kıyası kullanmışlar, başkalarına kıyas yapmalarını tavsiye etmişler ve bu davranışı kerih görmemişlerdir. Tâbiîn ve daha sonraki âlimler de benzer şekilde davranmışlardır. Onların birçok konuda ihtilaf etmiş olmaları da kıyas ve ictihad yoluyla amel ettiklerini bize kesin bir şekilde göstermektedir. ${ }^{33}$

Usûlcülerin çoğunun Muâz hadisi ile ilgili yaklaşımları Cessâs'ın değerlendirmelerine yakındır. Bâcî (öl. 474/1081), Şîrâzî (öl. 476/1083), Cüveynî (öl. 478/1085), Sem‘ânî (öl. 489/1096), Gazzâlî (öl. 505/1111) ve Osmanlı dönemi hukukçularından Molla Hüsrev (öl. 885/1480) gibi birçok usûlcü Muâz hadisinin usûlcüler nezdinde makbul bir hadis olduğunda hemfikirdir. Bu usûlcülere göre Muâz hadisi insanların/ümmetin/âlimlerin kabul ettikleri bir hadis olmuştur. ${ }^{34}$ Bu derece kabule mazhar olmuş bir hadisin mürsel olmasında ${ }^{35}$ ve ravilerinin mechûl olmasında bir sakınca

Hanefî Haber Teorisinin Oluşumundaki Rolü”, Eskişehir Osmangazi Üniversitesi İlahiyat Fakültesi Dergisi 6/10 (2019), 52.

30 Cessâs, el-Fusûl fi'l-usûl, 4/45-46.

31 Cessâs, el-Fusûl fi'l-usûl, $4 / 47$.

32 Cessâs, el-Fusûl fi'l-usûl, 4/49.

33 Cessâs, el-Fusûl fi'l-usûl, 4/52.

34 Ebû'l-Velîd Bâcî, İhkâmu'l-fusûl fì ahkâmi'l-usûl, thk. Abdulmecîd Türkî (Tunus: Dâru'l-Garbi'lİslâmî, 2008), 2/585-586; Ebû İshâk İbrâhîm b. Alî Şîrâzî, et-Tebsira fî usûli'l-fikh, thk. Muhammed Hasen Heyto (Dimaşk: Dâru'l-fikr, 1403), 1/425; Ebû'l-Muzaffer Mansûr b. Muhammed Sem'ânî, Kavâtı' 'u'l-edille fíl-usûl, thk. Muhammed Hasan İsmâîl (Beyrût: Dâru'l-kütübi'l-ilmiyye, 1999), 2/94; Ebû Hâmid Muhammed b. Muhammed b. Muhammed b. Ahmed et-Tûsî Gazzâlî, el-Mustasfâ min ilmi'l-usûl, thk. Muhammed Abdüsselâm Abdüşşâfî (Beyrut: Dâru'l-kütübi'l-ilmiyye, 1993), 1/293; Muhammed b. Ferâmûz Molla Hüsrev, Mir'âtü'l-usûl fî şerhi Mirkâti'l-vusûl (Dersaadet: Matbaa-i Osmâniye, 1312), 436.

35 Gazzâlî, el-Mustasfâ, 1/293. 
yoktur. ${ }^{36}$ Ayrıca bu hadisi, hiç kimse reddetmemiş, ta'n etmemiş ve inkâr etmemiştir. ${ }^{37}$ Böyle yaygınlık kazanan bir hadisin isnadını araştırmaya gerek yoktur. ${ }^{38} \mathrm{Bu}$ hadis, sahîh hadis kitaplarında (sıhâh) mevcut olup sıhhati üzerinde ittifak bulunmaktadır ve manası tevile ihtiyaç duyulmayacak kadar açıktır. ${ }^{39}$

Muâz hadisi Sünnî kaynaklarda -yukarıda da geçtiği üzere- başta kıyas ve ictihadın temel referanslarından kabul edilir. Bununla birlikte birçok alanda kaynak gösterilen ve delil olarak sunulan meşhur bir rivayettir. Bu hadis, İslam hukukunda devletin üç temel esası olan yasama, yürütme ve yargının temellendirilmesi bağlamında ortak referans olarak kullanıldığından ayrı bir ehemmiyete sahiptir. Şöyle ki bu rivayet yasama/teşri alanında kaynak olarak gösterilirken İslâm yargılama hukukunda da hâkimin hüküm verirken neye bağlı kalacağı noktasında da temel teşkil etmektedir. Ayrıca bu hadis, yargı ve yürütmenin kesin çizgilerle ayrılmadığı bir dönemde yürütme erki açısından da temel esas kabul edilebilir. ${ }^{40}$

\section{2. Şia Mezhebine Göre Muâz Hadisinin Kaynak Değeri}

Mezheplerin hukuk inşasında kullandıkları sistemlerinin ve yöntemlerinin benzerlik içermesi olağandır. Bu nedenle Şîilerin Sünnî ekolden birtakım yöntemleri aynen devralarak geliştirdikleri söylenebilir. Nitekim Müderrisîye göre Şeyh Tûsî (öl. 460/1068), Sünnî hukukun önemli bir kısmını Şiî hukuka dâhil etmiştir. Şiî hukukçu Musevi'ye göre Muhakkik el-Hillî (öl. 676/1277) ve Allâme el-Hillî (öl. 726/1325) eserlerindeki ictihad ve taklid konularındaki teorileri, Gazzâlî, Râzî (öl. 606/1210) ve Âmidînin (öl. 631/1233) eserlerinden esinlenerek kaleme alınmıştır. Şia'da ictihadın İslam hukukçuları tarafından kullanılmasını ve bu kavrama fikıh çalışmalarında yer verilmesini sağlayan ilk bilgin ise Muhakkik el-Hillî̀ dir. ${ }^{41}$

Şia mezhebi Sünnî ekolden birtakım yöntemleri almış olmakla birlikte iki tarafın en büyük ayrılık noktasını kıyas ve sünnet konuları teşkil etmektedir. Zira bu iki konu Şia mezhebi için hayati öneme sahip olan imamet fikriyle doğrudan ilgilidir. Şî̂ hadis literatürünün oluşması ve kabul görmesi Şia'da imamet anlayışının benimsenmesine ve Şiî kelamcıların argümanlarını yeni oluşan Şiî rivayetler üzerinden temellendirmelerine yol açmıştır. Bu durum aynı zamanda Şia mezhebinin kendi kabullerine aykııı bilgi ve rivayetleri de imamet anlayışlarına göre yorumlamalarını zorunlu

\footnotetext{
Bâcî, İhkâmu'l-fusûl, 2/586.

Bâcî, İhkâmu'l-fusûl, 2/586; Gazzâlî, el-Mustasfâ, 1/293.

Bâcî, íhkâmu'l-fusûl, 2/586; Gazzâlî, el-Mustasfâ, 1/293.

39 İmâmü'l-Haremeyn Ebü'l-Meâlî Rüknüddîn Abdülmelik b. Abdillâh b. Yûsuf Tâi Nîsâbûrî Cüveynî, elBurhân fi usûli'l-fikh, thk. Salâh b. Muhammed b. Uveyda (Beyrut: Dâru'l-kütübi'l-ilmiyye, 1997), 2/17. Cüveynî̀nin bu hadisin sahîh hadis kitaplarında (sıhâh) mevcut olup sihhati üzerinde ittifak bulunduğunu söylemesi bazı hadisçiler tarafından kendisine çok ağır eleştiriler yöneltilmesine sebep olmuştur. bk. Sevgili, “Cüveynînnin Hadisçiliği ve Hadisçiliğine Dâir Tartışmalar”, 235-240.

40 Muâz hadisinin yargılama alanındaki konumu için bk. Nasi Aslan, İslâm Hukukunda Yarglama Etiği ve Illkeleri (Adana: Karahan Kitabevi, 2019), 43.

${ }^{41}$ Cemil Hakyemez, "Şii İmamiyye Fıkhının Teşekkül Süreci ve İmamet", Hitit Üniversitesi Çorum îlahiyat Fakültesi Dergisi 7/13 (2008), 30-32.
} 
kılmıştır. Nitekim Şia'nın hicri üçüncü yüzyılın ortalarına doğru tamamen imam merkezli bir dini düşünceyi kabul etmesi, onların kelam ve hukuk anlayışlarını ciddi olarak biçimlendirmiş ve bu anlayışı destekleyen yeni rivayetler ya da bağlamlar oluşturulmuştur. Onların ictihad ve kıyas hususlarındaki yaklaşımı ve konuyla ilgili rivayet edilen hadisler, bu ayrışmanın ürünüdür ve bu noktada esas belirleyici faktör imamet meselesi olmuştur. ${ }^{42}$

Şii hadisçiler ile Şeyh Müfîd (öl. 413/1022), Şerîf Murtaza (öl. 436/1044) ve Tûsî gibi ilk usûlcülere göre kıyas mutlak geçersiz/batıl bir akıl yürütmedir. ${ }^{43} \mathrm{On}$ ların temel gerekçeleri kıyasın şer‘î delil olarak kullanılabileceğine dair bir delilin mevcut olmamasıdır. Şiî ilim adamları, kıyasın hüccet olduğuna dair Sünnî âlimler tarafından sunulan tüm delilleri ya farklı şekilde yorumlamışlar ya da sıhhatlerini inkâr etmişlerdir. Bu delillerden birisi de araştırma konumuz olan Muâz hadisidir.

\subsection{Muâz Hadisinin Sihhati}

Ehl-i Sünnet tarafından kıyasın şerî̀ bir delil olduğu ispat edilirken kullanılan Muâz hadisinin senedinde -daha önce de geçtiği üzere- mechûl raviler bulunmaktadır. Muâz b. Cebel'den rivayet edenler hakkında "Muâz'ın ashabı (arkadaşları)", "Muâz'ın arkadaşlarından bir kısım insanlar" șeklinde "nâs", "ünâs" ve "ricâl" gibi bir topluluğu ifade eden genel bir tabir kullanılmaktadır. Bu durum bazı Sünnî hadisçiler gibi Şiî usûlcüler tarafından da rivayetin eleştirilmesine neden olmuştur. Bu bağlamda Ehl-i Sünnet'in çoğunluğu tarafindan kıyas ve ictihadı ispat sadedinde bir delil olarak ileri sürülen ve kıyas ve ictihadın sahabe tarafından da kullanıldığına işaret eden güçlü bir delil olma özelliğini taşıyan Muâz hadisi, Şiî usûlcüler tarafından râvîleri meçhul bir haber-i vâhid olarak nitelendirilmiştir.

Şî̂ usûlcülere göre kesin bilgiyle temellendirilmesi gereken usûl konularında âhâd türü rivayetlerin delil olarak kullanılması doğru bir tutum değildir. ${ }^{44}$ Ayrıca haber-i vâhidlerle usûl konuları ispat edilse bile Muâz hadisi bu konuda delil olmaya elverişli değildir. Zira bu hadisin senedinde yer alan raviler mechûl şahsiyetlerdir. ${ }^{45}$ Çünkü ravisi Muğîre b. Şu'be'nin kardeşinin oğlu Haris b. Amr'dır. Haris de bu rivayeti Hıms'lı birkaç kişiden rivayet etmiştir. Ancak Haris bu hadisten başka bir hadisle bilinmeyen bir şahıstır. Dolayısıyla rivayette cehalet illeti bulunmaktadır.

Şî̂ âlimler tarafından Muâz hadisinin sıhhatine yöneltilen bir diğer eleștiri de hadisin mürsel olduğudur. Onlara göre bu hadis mürsel olduğu için de hüccet değeri

42 Hakyemez, "Şii İmamiyye F1khının Teşekkül Süreci ve İmamet”, 21-22; Kuzudişli, "Şia'da Rivayet Olgusunu Şekillendiren Temel Unsurlar", 59.

43 Alemü'l-hüdâ Ebü'l-Kâsım Alî b. el-Hüseyn b. Mûsâ b. Muhammed el-Alevî Şerîf Murtazâ, ez-Zerîa ilâ usûli'ş-şerîa, thk. Ebü'l-Kâsım Gürci (Tahran: y.y., 1346), 2/675; Ebû Ca'fer Muhammed b. el-Hasen b. Alî Tûsî, Uddetü'l-usûl, thk. Muhammed Riza el-Ensârî el-Kummî (Kum: y.y., 1417), 2/665-669.

44 Şerîf Murtazâ, ez-Zerîa, 2/773; Tûsî, Uddetü'-usûl, 2/718.

45 Şerîf Murtazâ, ez-Zerîa, 2/774-775; Tûsî, Uddetü'l-usûl, 2/710. 
yoktur. ${ }^{46}$ Ayrıca Muâz hadisinin insanların/ümmetin/âlimlerin kabulüne mazhar olduğu iddiası da doğru değildir. Onlara göre insanların/ümmetin/âlimlerin asırlardır bu haberi kabul ile telakki ettikleri bilinen bir durum olmadığı gibi bu tür haberlere karşı yeknesak bir tutum söz konusu değildir. ${ }^{47}$ Muâz hadisi ve benzeri haberleri kabul edenler olduğu gibi kabul etmeyenler de mevcuttur. ${ }^{48}$

\subsection{Muâz Hadisinin Kiyasa Delaleti}

Şî̂ âlimler tarafından Muâz hadisinin senedine ve sıhhatine yöneltilen eleştiriler bazı Sünnî hadisçilerin eleştirileriyle örtüşmektedir. Ancak Şîi âlimler Sünnî hadisçilerden farklı olarak senedinin tahlili yanında ayrıca metin tahlili yaparak hadisin kıyasa delalet etmeyeceğini savunmaktadırlar.

Bilindiği üzere Muâz hadisinde re'y lafzı kullanılmaktadır. Şî̂ âlimlere göre Ehli sünnet âlimler hadiste geçen re'y lafzını yanlış anlamaktadırlar. Re'y lafzının hadis ve sahabe kavillerindeki kullanım alanına bakıldığında kıyası da içine alan çok geniş bir anlam sahasına sahiptir. Buna göre re'y lafzı kayıtlardan bağımsız olarak kullanıldığında iddia edilenin aksine kıyasla elde edilen neticeye münhasır olmayıp şüphe, itiraz ve ihtilafa açı istidlal ile elde edilen neticeye şamildir. Ayrıca nassın zahirine ya da zahire istinad edilerek yapılan istidlallerin dikkate alınmasıyla varılan sonuca da bu kavram itlak olunmaktadır. ${ }^{49}$

Şiî âlimler, Muâz hadisindeki ve sahabeden nakledilen birçok ifadedeki re'y lafzının kıyas ve ictihaddan daha geniş bir anlama sahip olduğunu ayrıntılı şekilde izah etmeye çalışıllar. Örneğin "bir şahit ve yeminle yargılama yapılabileceği İmam Mâlik ve İmam Şâfiî̀nin re'yidir" denildiğinde burada anılan âlimlerin re'ylerinin dayanağı kıyas değil, haberdir. Aynı şekilde "Ebû Hanife'nin re'yine göre iddette dikkate alınacak ölçü tuhur değil hayızdır" denildiğinde onun dayanağı kıyasa muhalif bir çeşit istidlaldir. Dolayısıyla bu ve benzeri kullanımlarda sahabenin kendi yaklaşımını re'y lafzıyla dile getirmesi onların şer î hususlarda kıyas ile amel ettiklerini göstermez. Bu ve benzeri örneklerde görüldüğü üzere bilgi gerektiren delillere dayanılarak elde edilmiş olan çıkarımlara re'y denilmiştir. Dolayısıyla Muâz hadisinde bahsi geçen re'y lafzının da nassa dayanılarak ulaşılan sonuç anlamında re'y olması pekâlâ imkân dâhilindedir.

Şiî âlimler, re'y lafzının bu gibi farklı anlamlarda kullanıldığını birçok örnekle izah ederler. ${ }^{50}$ Netice olarak, onlara göre Muâz hadisi sahih olmadığı gibi söz konusu hadiste geçen "re'yimle ictihad ederim, re'yimle amel ederim" gibi ifadeler kıyasın

46 Ebü'l-Kâsım Necmüddîn Ca fer b. el-Hasen b. Ebî Zekeriyyâ Yahyâ el-Hüzelî Muhakkık el-Hillî, Meâricü'usûl, thk. Muhammed Hüseyn er-Rızavî (Kum: Müessesetü Âl-i Beyt, 1403), 193; Şeyh Muhammed Rıza Muzaffer, Usûlü'l-fikh (Beyrut: Müessesetü'l-A'lemi'l-Matbûât, 1410/1990), 2/167.

47 Şerîf Murtazâ, ez-Zerîa, 2/774; Tûsî, Uddetü'l-usûl, 2/711.

48 Mustafa Hayta, Klasik Dönem Şî̀-İmâmîFlkih Usulü Anlayışı (Doktora Tezi, Çukurova Üniversitesi, 2014), 249.

49 Şerîf Murtazâ, ez-Zerîa, 2/776-780.

50 Re'y ile ilgili Şiî usûlcüler tarafından yapılan yorumlar için bk. Hayta, şî̀-İmâmî Fikıh Usulü Anlayışı, 245249. 
şer î bir delil olduğuna delalet etmez. Ayrıca hadiste Muâz ictihad edeceğini ifade etmiş; fakat ne üzerinde ictihad edeceğini söylememiştir. ${ }^{51} \mathrm{O}$ halde haberin şu anlama geleceği inkâr edilemez: "Bir hâdise hakkında Kitap ve Sünnet'te -eğer Allah'ın Kitap ve Sünnetteki hükmüne ancak ictihadla ulaşlacaksa ve hüküm bu ikisinin zâhirinden anlaşllamıyorsa- Allah'ın hükmünü buluncaya dek ictihad ederim." Anlam böyle takdir edildiğinde kıyas taraftarlarının "ortak illetten hareketle aslın hükmünü fer'e vermek" 52 şeklindeki kıyas tanımına buradan bir delâlet veya bu tanımı doğrulayacak bir durum söz konusu olmayacaktır. ${ }^{53}$

\subsection{Muâz Hadisinin Farklı Varyantı}

Günümüzde yapılan bazı çalışmalarda Şiî âlimlerin rivayetler karşısındaki tutumları dikkate alındığında önemli iki unsur öne çımaktadır. Özellikle Şia ile Ehl-i Sünnet arasındaki ihtilaflı konularda rivayetlerin oluşturulmasında ve yorumlanmasında bu iki husus Şia'nın genel karakterini oluşturmaktadır. Bunlardan birincisi Şiî hadislerdeki imamet vurgusudur. Bu husus rivayetlerde sadece imamete yer verme ve imamın varlığını ispat etmenin ötesinde rivayetlerin imam merkezli yorumlanmasını, eğer yorumlanamıyorsa reddedilmesini ifade etmektedir.

Esasen Sünnî literatürdeki hadisler ile Şiî literatürdeki hadisler arasındaki en temel fark, Şiî hadislerde “imam" In varlı̆̆ı ve fonksiyonu olarak belirlenebilir. Şia'ya göre imamlardan rivayet edilen hadisler ile Hz. Peygamber'den rivayet edilen hadisler arasında bir fark bulunmadığı gibi ${ }^{54}$, mevcut hadislerin yorumlanmasında da masum imam anlayışı önemli bir faktör olmaktadır. Nitekim Şia'daki hadis rivayeti kendilerini Ehl-i sünnetten ayıran önemli unsurlardan biri olan imamet fikrini güçlü bir şekilde vurgular. ${ }^{55}$ Özellikle imamet konusu önce çocuk imamlar meselesiyle sonrasında ise küçük ve büyük gaybetle Şia için aşılması gereken önemli bir soruna dönüşmüştür. ${ }^{56}$ Bu bağlamda gelişen olaylara karşı bir yandan çeşitli eklemeler suretiyle rivayetler oluşturulmuş, diğer yandan Ehl-i sünnetteki hadisleri kendi lehlerine kullanmaya çalışmışlardır. ${ }^{57}$

Rivayetler karşısında Şia'nın genel karakterini oluşturan ikinci husus ise ihtilaflı konularda muhalife karşı konumlanmadır. Bu durum Şiî anlayışın genel itibariyle tepkisel bir zemin üzerine bina edilmiş olmasından kaynaklanmaktadır. Nitekim Şî̂ rivayetlerin kabulünde muhalife göre konumlanmanın bir yorumlama biçimi olduğu görülür. Onlara göre çelişen iki hadisten hangisinin doğru olduğunu bulma metotla-

\footnotetext{
Şerîf Murtazâ, ez-Zerîa, 2/776-777.

Şerîf Murtazâ, ez-Zerîa, 2/779.

53 Hayta, Şî̀-İmâmî Fıkıh Usulü Anlayışı, 250.

54 Kuzudişli, “Şia'da Rivayet Olgusunu Şekillendiren Temel Unsurlar”, 61.

55 Kuzudişli, "Şia'da Rivayet Olgusunu Şekillendiren Temel Unsurlar", 88.

56 Gaybet inancının Şiî imâmet nazariyesine etkisi için bkz. Hakyemez, Şîa'da Gaybet Ínancı, 203-206.

57 Kuzudişli, “Şia'da Rivayet Olgusunu Şekillendiren Temel Unsurlar”, 88-89. Benzer şekildeki hadisler için bk. Topgül, “Yeniden İnşa Edilen Hadis Bağlamları”, 45-83.
} 
rından birisinin "kavme (Ehl-i sünnete) muhalefet edenin alınması" şeklinde belirlenmesi bunun sonucu olarak kabul edilebilir. Zira Şia'ya göre doğru yol onlara muhalefet etmekten geçer. ${ }^{58}$ Şia'nın bu anlayışı hukukî konularda özellikle Sünnî uygulamalara aykırı rivayetlerin öne çıkarılmasına sebep olmuştur. ${ }^{59}$

Şîi kaynaklarda ilim ve dua gibi konulardan fikhî meselelere kadar geniş bir yelpazeyi kapsayan belirgin miktarda Ehl-i sünnet ile ortak hadisler bulunmaktadır. Bunların bir kısmı Muhammed el-Bâkır veya Cafer es-Sâdık gibi imamlar kanalıyla nakledilmişken bazıları da Ehl-i sünnet kitaplarında olduğu gibi "tabiûn-sahabe" tarikleriyle kaydedilir. Bu hadisler arasında birçok metin benzer olmakla birlikte iki ekolü ayrıştıran konularda kritik farklılıkların olduğu hadisler de bulunmaktadır. Bu hadislerde yapılan bazı değişiklikler ya da ilaveler Şia lehine önemli sonuçlar doğurabilmektedir. ${ }^{60}$

Şia'nın sahip olduğu imamet düşüncesi ve muhaliflere karşı konumlanma anlayışı, özellikle ihtilaflı konularda hadisleri yorumlarken ve haklılıklarını ispatlamak için tutundukları temel argümanları oluşturmaktadır. Muâz hadisi Şia'nın bu yaklaşımının tipik ve bir o kadar da ilginç bir örneğini teşkil etmektedir. Nitekim Ehl-i Sünnet tarafindan kıyasın güçlü bir delili olarak sunulan Muâz hadisi imamet fikrine ve imamın varlığına aykııı davranmayı gerektirir. Zira ictihad varsa imama ihtiyaç olmayacaktır. Daha önce de geçtiği üzere imam hem nassın kaynağı hem de yorumcusudur. Dolaylsıyla imamın varlı̆̆ı başkasının ictihad edebilmesine engel teşkil etmektedir.

Şiî usûlcüler Muâz hadisinin sahih olmadığını, sahih olduğu kabul edildiği takdirde de Ehl-i Sünnet tarafından iddia edildiği gibi kıyasa delalet edemeyeceğini vurgularlar. Tüm bu argümanların ardından ise Muâz hadisinin daha sahih bir varyantının olduğunu dile getirerek hadisin bu tarikinin delil olmaya daha elverişli olduğunu iddia ederler. Buna göre Hz. Peygamber Muâz’a "Sana arz edilen davanın hükmünü Allah'ın Kitab'inda ve Resûlullâh'in Sünnet'inde bulamazsan nasıl hükmedeceksin?" diye sorduğunda onun "Re'y ve ictihadımla amel ederim/hükmederim (ectehidu bira'yî)" demesi üzerine Hz. Peygamber "Hayır! Bana yaz/sor, ben de sana yazarım/cevap veririm" demiştir. ${ }^{61}$ Dolayısıyla bu rivayete göre Muâz çözümünü Kitap ve Sünnet'te bulamadığı konularda ictihad edemeyecek aksine Hz. Peygamber'in cevabını beklemek zorunda kalacaktır.

Şiî usûlcülerin öne çıkardıkları Muâz hadisinin ilgili varyantını İbn Mâce rivayet etmektedir. Ancak İbn Mâce rivayet ettiği bu haberde tek kalmıştır. ${ }^{62}$ Ayrıca

58 Ebû Cáfer Muhammed b. Ya'kûb Küleynî, el-Kâfi, thk. Ali Ekber el-Gaffârî (Tahran: Dâru'l-kütübi'lİslâmiyye, 1388/1968), 1/68.

59 Hakyemez, "Şii İmamiyye Fıkhının Teşekkül Süreci ve İmamet”, 21; Kuzudişli, “Şia’da Rivayet Olgusunu Şekillendiren Temel Unsurlar", 76-77.

60 Kuzudişli, “Şia'da Rivayet Olgusunu Şekillendiren Temel Unsurlar”, 83.

61 Şerîf Murtazâ, ez-Zerîa, 2/773-774; Tûsî, Uddetü'l-usûl, 2/711.

62 Muâz hadisinin bu varyantıyla ilgili değerlendirmeler için bk. Mehmet Emin Özafşar, "Polemik Türü Rivâyetlerin Gerçek Mâhiyeti”, İslâmiyât 1/3 (1998), 47; Ahmet Özcan, Muâz ibn Cebel'in Hayatı ve Hadis Rivayetindeki Yeri (Yüksek Lisans Tezi, Eskişehir Osmangazi Üniversitesi SBE, 2013), 61-62. 
Bâcî, usûlünde benzer rivayeti muallak olarak nakletmekte ve hadisle ilgili değerlendirmelerde bulunmaktadır. O, Muâz hadisinin bu varyantının kıyasın delili olarak kullanılan diğer varyantı kadar meşhur olmadığını belirterek, tercih noktasında mukayese edilemeyeceğini söylemektedir. Zira selef, Muâz hadisini kabul ederek onunla amel etmiş diğer varyantını ise kabul etmeyerek reddetmiştir. Ayrıca Bâcî, Muâz hadisiyle ilgili farklı varyantların netice olarak şu şekilde telif edilebileceğini belirtmektedir: “Eğer sana Allah'ın kitabında ve Resûlullâh'ın Sünnet'inde bulamadığın bir dava gelirse ictihâd et. Ancak çözemediğin, içinden çıkamadığın mesele olursa bana yaz". ${ }^{63}$

Bazı araştırmacılara göre hadisin bu versiyonu özellikle hicrî ikinci asrın sonlarından itibaren belirginleşen re'y karşıtı zihniyetin sonucudur. ${ }^{64}$ Bununla birlikte k1yasın batıl olduğunu belirten Şiî usûlcüler, Muâz hadisinin bu varyantını öne çıarmışlardır. Görüldüğü üzere “Hz. Peygamber'e sorması ve cevabını beklemesini” ifade eden rivayetin öne çıkarılması ve vurgulanması Şia lehine çok önemli bir sonuç doğurmaktadır. Zira meşhur olduğu şekliyle Muâz hadisi re'yin/kıyasın şer î bir delil olduğunu vurgulamaktadır. Dolayısıyla rivayet bu haliyle Şia'nın her dönemde bulunması zorunlu olan imam fikrine, dolayısıyla Şia'nın sünnet anlayışına aykırıdır. Ancak Şia'nın öne çıkardığı Hz. Peygamber'in “Hayır! Bana yaz/sor, ben de sana yazarım/cevap veririm" şeklindeki rivayette ise imamet fikrine vurgu yapılmakta ve kıyasa yani hür ictihadî görüşe $e^{65}$ değil imamın görüşüne müracaat edilmesini istemektedir.

Son dönem Şiî akademisyenlerinden Muhammed Tîcânînin konuyla ilgili ifadeleri Şia'nın Muâz Hadisi'ne yaklaşımını özetler niteliktedir. Ona göre Muâz Hadisi, ictihad ve re'y ehlinin kendi görüşlerini desteklemek ve hakka batılı karıştırmak için uydurmuş olduğu hadislerden biridir. Hz. Peygamber ile Muâzb. Cebel arasında böyle bir konuşmanın geçmiş olması ve özellikle Hz. Peygamber'in Muâz’a "Eğer Allah'ın Kitâbı'nda o hükmü bulamazsan ne yapacaksın (nasıl hükmedeceksin)?” demesi imkân dâhilinde değildir. ${ }^{66}$ Nitekim Şiî hadis müellifi Nu'mânî (öl. 360/971) de Muâz hadisinin Hz. Peygamber'e yapılmış büyük bir iftira olduğunu iddia etmiştir. ${ }^{67}$

\section{Sonuç}

Şia mezhebi Sünnî ekolden birtakım yöntemleri almış olmakla birlikte iki tarafın en büyük ayrılık noktasını kıyas ve sünnet konusu teşkil etmektedir. Zira bu iki konu Şia mezhebi için hayati öneme sahip olan imamet fikriyle doğrudan ilgilidir. Özellikle Şî̂ hadis literatürünün oluşması ve kabul görmesi imamet fikrinin tamamen

63 Bâcî, İhkâmu'l-fusûl, 2/586-587.

64 Özafşar, "Polemik Türü Rivâyet”, 46.

65 bk. Nasi Aslan - Ömer Zahid Aslan, “Özgür Düşüncenin Fıkhî Tezâhürü -İctihat Kurumu-”, 5. Uluslararası Sosyal Bilimler Kongresi (Üsküp/Kuzey Makedonya 2019, (Ankara: Sageya Yayınc1lı, 2019), 841-845.

66 Muhammed Tîcânî, eş-Şîa hum ehlü's-sünne (b.y.: y.y., ts.), 155.

${ }^{67}$ Ebû Zeyneb Muhammed b. İbrahim Nu'mânî, Kitâbu'l-gaybe, thk. Fâris Hasûn Kerim (Kum: Envâru'lhüdâ, 1422), 54 . 
benimsenmesine ve Şiî kelamcıların temel anlayışlarını yeni oluşturulan Şiî rivayetler üzerine bina etmelerine yol açmışıı. Bu durum aynı zamanda Şia mezhebinin kendi kabullerine aykırı bilgi ve rivayetleri de imamet anlayışlarına göre yorumlamalarını zorunlu kılmıştır.

Muâz hadisi Şia'nın bu yaklaşımının tipik ve bir o kadar da ilginç bir örneğini teşkil etmektedir. Nitekim Ehl-i Sünnet tarafından kıyasın güçlü bir delili olarak sunulan Muâz hadisi imamet fikrine ve imamın varlı̆̆ına aykırı bilgiler ihtiva etmektedir. Zira ictihad varsa imama ihtiyaç olmayacaktır. Daha önce de geçtiği üzere Şia'da imam hem nassın kaynağı hem de yorumcusudur. Dolayısıyla imamın varlığı başkasının ictihad edebilmesine engel teşkil etmektedir. Bu nedenle Şiî usûlcüler Muâz hadisinin sahih olmadığını, sahih olduğu kabul edildiği takdirde de Ehl-i Sünnet tarafından iddia edildiği gibi kıyasa delalet etmediğini savunurlar. Buna ilaveten Şiî âlimler, Muâz hadisinin farklı bir varyantının olduğunu dile getirerek hadisin bu tarikinin delil olmaya daha elverişli olduğunu iddia ederler. Buna göre Hz. Peygamber Muâz’a “Sana arz edilen davanın hükmünü Allah'ın Kitab'inda ve Resûlullâh'n Sünnet'inde bulamazsan nasıl hükmedeceksin?" diye sorduğunda onun "Re'y ve ictihadımla amel ederim/hükmederim (ectehidu bi-ra'yî)" demesi üzerine Hz. Peygamber "Hayır! Bana yaz/sor, ben de sana yazarım/cevap veririm" demiştir. Dolayısıyla bu rivayete göre Muâz çözümünü Kitap ve Sünnet’te bulamadığ konularda ictihad edemeyecek aksine Hz. Peygamber'in cevabını beklemek zorunda kalacaktır.

Kıyasın batıl olduğunu belirten Şiî usûlcüler Muâz hadisinin söz konusu varyantını öne çıkarmışlardır. Görüldüğ̈̈ üzere "Hz. Peygamber'e sorması ve cevabını beklemesi”ni ifade eden bu rivayetin öne çıkarılması ve vurgulanması Şia lehine çok önemli bir sonuç doğurmaktadır. Zira meşhur olduğu şekliyle Muâz hadisi hem re'yin/kiyasın şer'î bir delil olduğunu göstermekte hem de her dönemde bulunması zorunlu olan imam fikrine, dolayısıyla Şia'nın sünnet anlayışına aykırılık arz etmektedir. Şia'nın öne çıkardığı rivayette Hz. Peygamber'in "Hayır! Bana yaz/sor, ben de sana yazarım/cevap veririm" şeklindeki cevabı ise imamet fikrine vurgu yapmakta ve kıyasa yani hür ictihadî görüşe değil imamın görüşüne müracaat edilmesini istemektedir. Buna göre hükmü Kur'ân ve Sünnet'te yer almayan bir meselenin çözümünde Şî̂ âlimlerin ictihada başvurmayıp masum imama sormaları gerekmektedir. Sonuç olarak âyetlerin ve Sünnî hadis kaynaklarında yer alan hadislerin yorumlanmasında önemli bir fonksiyon icra eden masum imam anlayışının Muâz hadisinin yorumlanmasında da etkili olduğu anlaşılmaktadır.

Etik Beyan / Ethical Statement

Yazar / Author
Bu çalışmanın hazırlanma sürecinde bilimsel ve etik ilkelere uyulduğu ve yararlanılan tüm çalışmaların kaynakçada belirtildiği beyan olunur / It is declared that scientific and ethical principles have been followed while carrying out and writing this study and that all the sources used have been properly cited.

Ömer Korkmaz 


\section{Kaynakça}

Akgül, Yusuf. "Fıkıh Usulüne Kaynaklığı Açısından Muâz Hadisinin Tahlili ve Tenkidi”. Bozok Üniversitesi İlahiyat Fakültesi Dergisi 13/14 (2018), 193-222.

Aslan, Nasi. İslâm Hukukunda Yargllama Etiği ve ilkeleri. Adana: Karahan Kitabevi, 2019.

Aslan, Nasi - Aslan, Ömer Zahid. “Özgür Düşüncenin Fıkhî Tezâhürü -İctihat Kurumu-”. 5. Uluslararası Sosyal Bilimler Kongresi (Üsküp/Kuzey Makedonya 2019. 841-845. Ankara: Sageya Yayınc1lk, 2019.

Atik, Sefa. Sünnîliğin İzinde Caferî Fıkıh Usulünde Akıl. İstanbul: Pınar Yayınları, 2017.

Bâcî, Ebû'l-Velîd. İhkâmu'l-fusûl fi ahkâmi'l-usûl. thk. Abdulmecîd Türkî. Tunus: Dâru'l-Garbi'l-İslâmî, 2008.

Beyhakî, Ahmed b. el-Huseyn b. Ali. es-Sunenu's-suğrâ. thk. Abdulmu'tî Emin Kal'acî. Pakistan: Câmi'atu'd-Dirâsâti'l-ìslâmiyye, 1989.

Beyhakî, Ahmed b. Huseyn b. Ali. es-Sunenu'l-kubrâ. thk. Muhammed Abdulkâdir Atâ'. Beyrut: Dâru'lKutubi'l-illmiyye, 2003.

Buhârî, Ebû Abdullah Muhammed b. İsmâîl b. İbrâhîm el-Cu'fi. et-Târîhu'l-kebîr. Haydarâbâd: Dâru'lmaârifi'l-Osmâniyye, 1361-1364.

Cessâs, Ebû Bekr Ahmed b. Ali er-Râzî. Ahkâmü'l-Kur'ân. thk. Abdüsselam Muhammed Ali Şahin. Beyrut: Dâru'l-kütübi'l-ilmiye, 1415/1994.

Cessâs, Ebû Bekr Ahmed b. Ali er-Râzî. el-Fusûl fi'l-usûl. Kuveyt: Vezâretü'l-Evkâfi'l-Kuveytiye, 1994.

Cessâs, Ebû Bekr Ahmed b. Ali er-Râzî. Şerhu Muhtasarit-Tahâvî. thk. İsmetullâh İnâyetüllâh Muhammed vdğ. Beyrut: Dâru Beşâiri'l-İslâmiyye - Dâru's-Sirâc, 2010.

Cüveynî, İmâmü'l-Haremeyn Ebü’l-Meâlî Rüknüddîn Abdülmelik b. Abdillâh b. Yûsuf Tâî Nîsâbûrî. elBurhân fi usûlil-fikh. thk. Salâh b. Muhammed b. Uveyda. Beyrut: Dâru'l-kütübi'l-ilmiyye, 1997.

Çiftçi, Şaban. "Hadis Eğitiminde Usul-Pratik Bütünlüğü "Muâz Hadisi” Örneği”. Abant İzzet Baysal Üniversitesi Eğitim Fakültesi Dergisi 11/2 (2015), 55-64.

Dârekutnî, Ebû'l-Hasen Ali b. Ömer. el-'ilelu'l-vâride fill-ehâdîsinn-nebeviyye. thk. Mahfûzu'r-Rahmân Zeynullâh. Riyâd: Dâru Taybe, 1985.

Dârimî, Abdullâh b. Abdurrahmân. Sunenu'd-Dârimî. thk. Huseyn Selim Esed. Riyâd: Dâru'l-Muğnî, 2000.

Gazzâlî, Ebû Hâmid Muhammed b. Muhammed b. Muhammed b. Ahmed et-Tûsî. el-Mustasfâ min ilmi'lusûl. thk. Muhammed Abdüsselâm Abdüşşâfi. Beyrut: Dâru'l-kütübi'l-ilmiyye, 1993.

Gül, Sema. "Muâz b. Cebel'in Yemen'e Gönderilmesiyle İlişkilendirilen Rivâyetlerin Şekil Yönünden Tahlili”. Iğdır Üniversitesi İlahiyat Fakültesi Dergisi 6 (2015), 183-208.

Hakyemez, Cemil. “Şii İmamiyye Fıkhının Teşekkül Süreci ve İmamet”. Hitit Üniversitesi Çorum İlahiyat Fakültesi Dergisi 7/13 (2008), 7-36.

Hakyemez, Cemil. Şî'da Gaybet İnancı ve Gâib On İkinci İmam. İstanbul: İSAM Yayınları, 2009.

Hayta, Mustafa. Klasik Dönem Şî̀-İmâmî Fıkıh Usulü Anlayıışı. Doktora Tezi, Çukurova Üniversitesi, 2014.

İbn Hanbel, Ahmed b. Muhammed. Musnedul-İmâm Ahmed b. Hanbel. thk. Şu'ayb Arnâût - Âdil Murşid. b.y.: Muessesetu'r-Risâle, 2001.

İbn Hazm, Ebû Muhammed b. Ali b. Ahmed b. Sa îd ez-Zâhirî. el-Muhallâ bi'l-âsâr. Beyrût: Dâru'l-Fikr, ts.

İbn Hazm, Ebû Muhammed b. Ali b. Ahmed b. Sa îd ez-Zâhirî. el-İhkâm fi usûli'l-ahkâm. thk. Ahmed Muhammed Şâkir. Beyrut: Dâru'l-Âfâki'l-Cedîde, ts.

Kandemir, M. Yaşar. “el-Müsned”. TDV İslâm Ansiklopedisi. 32/103. İstanbul: TDV Yayınları, 2006.

Kuzudişli, Bekir. “Şia'da Rivayet Olgusunu Şekillendiren Temel Unsurlar”. Dinbilimleri Akademik Araştırma Dergisi 18/1 (2018), 59-92.

Küleynî, Ebû Ca'fer Muhammed b. Ya kûb. el-Kâfi. thk. Ali Ekber el-Gaffârî. Tahran: Dâru'l-kütübi'lİslâmiyye, 1388/1968. 
Molla Hüsrev, Muhammed b. Ferâmûz. Mir'âtü'l-usûl fî şshi Mirkâti'l-vusûl. Dersaadet: Matbaa-i Osmâniye, 1312.

Muhakkık el-Hillî, Ebü'l-Kâsım Necmüddîn Ca'fer b. el-Hasen b. Ebî Zekeriyyâ Yahyâ el-Hüzelî. Meâricü'l-usûl. thk. Muhammed Hüseyn er-Rızavî. Kum: Müessesetü Âl-i Beyt, 1403.

Muzaffer, Şeyh Muhammed Rıza. Usûlü'l-fikh. Beyrut: Müessesetü'l-A'lemi'l-Matbûât, 1410/1990.

Nu'mânî, Ebû Zeyneb Muhammed b. İbrahim. Kitâbu'l-gaybe. thk. Fâris Hasûn Kerim. Kum: Envâru'lhüdâ, 1422 .

Orhan, Fatih. “İmam Serahsînin Hanefî Haber Teorisinin Oluşumundaki Rolü”. Eskişehir Osmangazi Üniversitesi İlahiyat Fakültesi Dergisi 6/10 (2019), 39-60.

Özafşar, Mehmet Emin. “Polemik Türü Rivâyetlerin Gerçek Mâhiyeti”. İlâmiyât 1/3 (1998), 19-48.

Özcan, Ahmet. Muâz ibn Cebel'in Hayatı ve Hadis Rivayetindeki Yeri. Yüksek Lisans Tezi, Eskişehir Osmangazi Üniversitesi SBE, 2013.

Özkan, Halit. “Tayâlisî”. TDV İslâm Ansiklopedisi. 40/188-189. İstanbul: TDV Yayınları, 2011.

Sem 'ânî, Ebû'l-Muzaffer Mansûr b. Muhammed. Kavâtı 'u'l-edillefi'l-usûl.thk. Muhammed Hasan İsmâ̂̂l. Beyrût: Dâru'l-kütübi'l-ilmiyye, 1999.

Sevgili, Mehmet Macit. "Bir Usûlcü Olarak Cüveynînnin Hadisçiliği ve Hadisçiliğine Dâir Tartışmalar “Mu'âz Hadisi” Özelinde-”. Sakarya Üniversitesi İlahiyat Fakültesi Dergisi 20/37 (2018), 217-246. https://doi.org/10.17335/sakaifd.406384

Sicistânî, Ebû Dâvûd Suleymân b. Eş‘as Ezdî. Sunenu Ebî Dâvûd. thk. Muhammed Muhyiddîn. Beyrut: el-Mektebetu'l-Asriyye, ts.

Şâfiî, Ebû Abdullah Muhammed b. İdris b. Abbas. Kitâbü'l-Üm. Beyrut: Dâru'l-marife, 1410/1990.

Şerîf Murtazâ, Alemü'l-hüdâ Ebü'l-Kâsım Alî b. el-Hüseyn b. Mûsâ b. Muhammed el-Alevî. ez-Zerîa ilâ usûli'ş-şerî'a. thk. Ebü'l-Kâsım Gürci. Tahran: y.y., 1346.

Şirâzî, Ebû İshâk İbrâhîm b. Alî. et-Tebsira fi usûli'l-fikh. thk. Muhammed Hasen Heyto. Dımaşk: Dâru'lfikr, 1403.

Taberânî, Ebû'l-Kâsım Suleyman b. Ahmed. el-Mu'cemu'l-kebîr. thk. Hamdi b. Abdulmecid Selefi. Kâhire: Mektebetu İbn Teymiyye, 1994.

Tahâvî, Ebû Ca'fer Ahmed b. Muhammed b. Selâme el-Ezdî el-Hacrî el-Mısrî. Şerhu müşkili'l-âsâr. thk. Şuayb el-Arnaût. Beyrut: Müessesetü'r-risâle, 1415/1994.

Tayâlisî, Ebû Dâvûd Süleymân b. Dâvûd b. el-Cârûd. Müsnedu Ebî Dâvûd Tayâlisî. thk. Muhammed b. Abdülmuhsin et-Türkî. Cize: Dâru Hicr li’t-T1bâa ve'n-Neşr, 1419/1999.

Tîcânî, Muhammed. eş-Şîa hum ehlü's-sünne. b.y.: y.y., ts.

Tirmizî, Muhammed b. Îsâ. Sunenu't-Tirmizî. thk. Ahmed Muhammed şâkir. Misır: Matbaatu Mustafa el-Bâbî, 1975.

Topgül, Muhammed Enes. "Sünnî-Şî̂ İkilemine Farklı Bir Bakış: Yeniden İnşa Edilen Hadis Bağlamları”. İslâm Araştırmaları Dergisi 41 (2019), 45-83. https://doi.org/ 10.26570/isad.513132

Tûsî, Ebû Ca'fer Muhammed b. el-Hasen b. Alî.Uddetül'-usûl.. thk. Muhammed Rıza el-Ensârîel-Kummî. Kum:y.y., 1417. 